\title{
A FORMAÇÃO DE PROFESSORES DE ARTES VISUAIS NA CONTEMPORANEIDADE: REFLEXÕES FILOSÓFICAS
}

\author{
LA FORMACIÓN DE PROFESORES DE ARTES VISUALES EN LA CONTEMPORANEIDAD: REFLEXIONES \\ FILOSÓFICAS
}

Resumo: A pretensão desta escrita é articular autores cujas linhas de pensamento ajudem a fundamentar uma formação para professores de artes visuais que atuam na escola básica brasileira. Para isso, é necessário compreender com profundidade o conceito de arte e o que a diferencia, radicalmente, da cultura. Neste contexto de formação, outras questões precisam ser discutidas como: o espaço escolar, a atuação do professor que vivencia esse espaço de aprendizagem e primordialmente o aluno, sujeito para o qual a formação continuada se destina. A relação subjetiva professor e aluno também precisa ser revista, se o que se quer alcançar são novos modos de formação e aprendizagem escolar.

Palavras Chave: Arte. Formação. Cultura. Educação.
Janaína Corá Cláudia Battestin²

\section{PENSAR A ARTE A PARTIR DE UMA REFLEXÃO FILOSÓFICA}

Para pensar a formação dos professores de artes visuais, tomaremos como eixo norteador o título do livro de Jacques Rancière (1940-), A partilha do sensível, traduzido e publicado no Brasil no ano de 2005. Para o pensador francês, a noção de partilha implica em repartir, distribuir. Na nota de tradução do livro, a participação em um conjunto comum é conceituada pelo autor:

Denomino partilha de sensível o sistema de evidências sensíveis que revela [...] a partilha do sensível fixa portanto, ao mesmo tempo, um comum partilhado e partes exclusivas. Essa repartição das partes de espaços e dos lugares se funda numa partilha de espaços, tempos e tipos de atividades que determina propriamente a maneira como um comum se presta à participação e como uns e outros tomam parte nesta partilha (2005, p.15).

Rancière (2005) reflete sobre a necessidade de se compartilhar saberes e fazeres com o outro, de preferência em espaços públicos e abertos, como por exemplo, a escola. Para o autor, a cidadania passa por um exercício comunitário da estética e da política. Por sinal, a estética é um dos campos de saber que fundamentam a história da arte e a produção artística, bases da formação acadêmica do professor

\footnotetext{
${ }^{1}$ Mestranda na Universidade Comunitária da região de Chapecó. Professora de artes na rede estadual de Santa Catarina. E-mail: janainacora@unochapeco.edu.br. ORCID: https://orcid.org/0000-0001-9108-0496.

${ }^{2}$ Doutora em Educação pela Universidade Federal de Pelotas - UFpel. Professora do Mestrado em Educação da Universidade Comunitária da região de Chapecó. E-mail: claudiabattestin@hotmail.com. ORCID: http://orcid.org/0000-0001-7871-9275.
} 
que ensina arte na escola.

A política, ainda de acordo com Rancière, não se limita apenas ao meio de organizar e/ou governar. Trata-se, antes de tudo, de um conflito de reivindicação pela igualdade, conflito esse, que implica um modo de viver em meio à coletividade, ou seja, não existe partilha, nem política individualmente, o eu sempre estará vinculado ao outro. A grande contribuição teórica de Rancière talvez esteja na constatação de que há uma estética na base da política”, ou seja, “(...) hoje em dia, é no terreno estético que prossegue uma batalha ontem centrada nas promessas da emancipação e nas ilusões e desilusões da história" (2005, p 12).

Neste contexto, torna-se importante para o professor de arte discernir claramente sobre o que é a arte e o que a diferencia da cultura. O esclarecimento acerca destas questões pode contribuir para pensar as políticas públicas de formação de professores de artes nas escolas, possibilitando uma nova perspectiva sobre o currículo escolar da disciplina, colocando-o a par dos desafios do viver na contemporaneidade.

O termo estética é um termo recente se comparado ao uso de outras palavras que acompanham a história da filosofia. A palavra Aesthetica foi usado pela primeira vez pelo alemão Alexander Baumgarten em 1735.0 filósofo britânico Terry Eagleton (1943-) escreve que esse nascimento é assinalado como um discurso sobre o corpo, "o termo não se refere primeiramente à arte, mas, como o grego aisthesis, a toda região da percepção e sensação humanas" (1993, p. 17). A estética em meados do século XVIII, segundo o autor, não é aquela entre arte e vida, mas entre o material e o imaterial: entre coisas e pensamentos, sensações e ideias.

É como se a filosofia acordasse subitamente para o fato de que há um território denso e crescendo para além de seus limites (...) a totalidade de nossa vida sensível - o movimento de nossos afetos e aversões, de como o mundo atinge o corpo em suas superfícies sensoriais, tudo aquilo que enfim enraíza no olhar e nas vísceras e tudo o que emerge de nossa mais banal inserção biológica no mundo. (...) de uma longa e inarticulada rebelião do corpo contra a tirania do teórico. (EAGLETON, 1993, p.17)

Para Eagleton, o fato da filosofia clássica ter ignorado tudo o que pertence à vida somática e sensual de uma sociedade, teve um custo político, ou seja, a demanda por estética na Alemanha no século XVIII, é uma resposta ao problema do absolutismo político, a estética como parte da razão:

A construção da noção moderna do estético é inseparável da construção das formas ideológicas dominantes da sociedade de classes modernas, e na verdade, de todo um novo formato da subjetividade apropriado a esta ordem social. É em função disso, e não de um súbito despertar de homens e mulheres para o valor superior da poesia e da pintura, que a estética assumiu esse papel tão importuno na herança intelectual do presente. Porém minha tese é também a de que a estética, entendida num sentido determinado, coloca igualmente um desafio e uma alternativa poderosos a estas mesmas formas ideológicas dominantes. Trata-se, assim, de um fenômeno igualmente contraditório. (EAGLETON, 1993, p. 08)

Sobre a questão da estética, Giorgio Agamben em sua obra O homem sem conteúdo (2012), descreve em linhas gerais, a crítica de Nietzsche a Kant, uma vez que os mesmos possuíam um ponto de discordância em relação à arte. Esse ponto nos parece fundamental, Agambem (2012, p.17) explica que Nietzsche acusa Kant de considerar o problema da estética única e exclusivamente a partir da experiência do espectador, daquele que contempla a obra de arte. Para Kant, o juízo de valor do

${ }^{3}$ Tais ideias estão implícitas nas obras de Walter Benjamin, Max Horkeiheimer e Theodor Adorno. 
indivíduo determinaria o conceito de beleza, sendo o belo a expressão máxima que uma obra pode atingir: "A faculdade de ajuizamento de um objeto ou de um modo de representação mediante uma complacência ou uma descomplacência independente de todo interesse" (2002, p. 55).

Na esteira desse pensamento kantiano - que ainda hoje fundamenta "apreciação artística" no senso comum - a arte deve agradar, fazer bem ao espectador, sem interesses, enriquecê-lo com conhecimentos. Ver uma obra seria um estado de contemplação desinteressada. $O$ homem de gosto ou seja, o espectador de Kant - é aquele que passeia pelos museus, observa, olha atentamente e julga a obra de arte.

Em oposição, Nietzsche observou que esse espectador de Kant pode até possuir o seu juízo de gosto, mas é incapaz de produzir a obra. Nietzsche vai mais fundo e estende sua crítica ao próprio museu $^{4}$, como o lugar privilegiado da arte na era estética, ou seja, lugar para a elite. Isso quer dizer: o museu como o lócus de desvinculação da origem e do contexto em que a obra foi produzida.

De agora em diante, senhores filósofos, guardemo-nos bem contra a antiga, perigosa fábula conceitual que estabelece um "puro sujeito do conhecimento, isento de vontade, e alheio à dor e ao tempo", guardemo-nos dos tentáculos de conceitos contraditórios(...); e quanto mais afetos permitirmos falar sobre uma coisa, quanto mais olhos, diferentes olhos soubermos utilizar para essa coisa, tanto mais será nosso "conceito" dela, nossa "objetividade". Mas eliminar à vontade inteiramente, suspender os afetos todos sem exceção, supondo que o conseguíssemos: como? - não seria castrar o intelecto?... (NIETZCHE, 1988, p.134).

Uma das ideias centrais do texto de Agamben é que “(...) a entrada da arte no campo da estética teve consequências não só para os espectadores, como para os próprios artistas e para as obras de arte em geral" (2012, p. 200)5. Isso significa que a estética não é mais somente sinônimo de contemplação da beleza e prazer do fenômeno artístico, mas um exercício daquele que pensa o mundo ao seu redor a partir de pressupostos artísticos.

Se, para Rancière (2005), existe uma estética na base na política, então, toda arte é por assim dizer, também política. A arte para Nietzsche (1988) é a que está atenta, quer dizer, interessada nos problemas e percalços da vida social humana. A arte não está mais, a serviço da história, ela não é apenas uma fonte que futuramente pode contar a história de seu tempo. A obra de arte é capaz de modificar a história, inventando novos modos de sentir e de olhar, produzindo discursos e debates. Pode-se dizer que essa é a diferença do que foi produzido na arte no período clássico em relação à arte produzida a partir da modernidade. A compreensão dessa diferença é primordial para a formação do professor de artes visuais na contemporaneidade.

Nesta ótica, segundo a escrita de lannini, no prefácio de O homem sem conteúdo de Agambem (2012), Nietzsche procuraria pensar uma arte para artistas: "Uma arte, de alguma forma, fora do regime da apreciação desinteressada. Ora, a arte interessada é também o campo do perigo" (2012, p.10). A arte, ao invés de ser um problema estético e de gosto, passa a ser o lugar, por excelência, do homem na modernidade e na pós-modernidade.

\footnotetext{
${ }^{4}$ Essa crítica nietzschiana ao museu seria desenvolvida em um texto com caráter de crônica do poeta Paul Valery, intitulado "Museu Valery-Proust". Mais recentemente, o tema foi desenvolvido também de modo crítico em dois livros fundamentais sobre o assunto: "No interior do cubo branco", de Brian O’Doherty, e Sobre as ruínas dos museus, de Douglas Crimp.

${ }^{5} \mathrm{O}$ subtítulo do capítulo $V$ de seu livro é uma frase do poeta Lautréamont (1846-1870): “juízos sobre a poesia têm mais valor que a poesia” para se referir à consequência extrema que chegou o juízo estético.
} 
O artista, para Nietzsche, é aquele que passa a correr riscos. “(...) ver assim diferente, querer ver assim diferente, é uma grande disciplina e preparação do intelecto para a sua futura "objetividade" - a qual não é entendida como observação desinteressada" (1988, p.133).

A arte para aquele que cria é uma experiência cada vez mais inquietante, ou "a coisa mais inquietante". Nas palavras do poeta Rainer Maria Rilke: "As coisas estão longe de serem todas tão tangíveis e dizíveis quanto se nos pretenderia fazer crer; a maior parte dos acontecimentos é inexprimível e ocorre num espaço em que nenhuma palavra nunca pisou" (1953, p. 21). Um exemplo é como o pintor francês Henri Matisse (1869-1954) relata o seu trabalho. Ele costumava dizer que nunca começou um quadro, uma pintura sem sentir medo, como se estivesse sempre arriscando a própria vida:

Não, é impossível [esquecer que sou Henri Matisse]. Sou escravo desta mesa. Às vezes digo a mim mesmo: que belo dia! Como seria agradável fazer um pequeno passeio: ir aqui perto ver Rouault ou Bonnard! Mas penso na tinta que secaria na tela, estou preso à obra, e se me afasto fico cheio de remorsos. Da mesma forma, à noite só consigo dormir depois de preparar o trabalho para o dia seguinte. Eu me agarro à pintura como um animal àquilo que ama. (2007, p.31)

Para nos aprofundarmos nessa reflexão sobre a estética, iremos nos referir à assertiva que inicia o texto intitulado "A pintura pensa", presente no livro A pintura encarnada, de Georges Didi-Huberman. Ele descreve o artista que padece em torno de sua obra, e se vê enredado nos limites da representação. Esse artista está numa trincheira, em busca do que “(...) a um só tempo compreende sua raiva, o pensamento de suas irrepresentabilidades de direito e o sonho de sua mais alta eficácia" (2012, p.12). Para o autor, a potência da arte está também em interrogar o tom de certeza que impera na bela disciplina de história da arte, compreendida por Agamben, com as seguintes palavras:

[...] ruptura com tradição não significa de fato a perda ou a desvalorização do passado: é, antes, bem provável que apenas então o passado se revele enquanto tal com um peso e uma influência antes desconhecida [...] Nessa situação, o homem conserva essa herança cultural, e o valor desta, aliás, se multiplica vertiginosamente: ele perde, porém, a possiblidade de extrair dela o critério de sua ação e da sua salvação. (2012, p. 174).

Didi-Huberman relembra o problema central do livro A Obra-prima desconhecida, de Honoré Balzac: “(...) a causa final da pintura é um além da prática da pintura. Quem procurar a pintura acabada, sabe que não a terá encontrado" (2012, p.23). É nesse sentido que, para Agamben (2012), a potência da obra está na própria obra, porque o lugar da arte passa a ser uma busca sem garantias.

Outra observação importante a ser feita aqui, é a diferença radical existente entre "arte" e "cultura". Embora aparentemente próximas, muitas vezes utilizadas como sinônimas, é preciso distingui-las com clareza, para saber exatamente o que se trabalhar em sala de aula.

Utilizaremos aqui as reflexões de Jean-Luc Godard (1930-), em um de seus curta-metragens, um filme de dois minutos e catorze segundos de duração, chamado JeVous Salue Sarajevo, de 1993. Nele, uma única imagem, uma foto de guerra tirada na Bósnia pelos fotógrafos Ron Haviv e Luc Delahaye. Soldados tratam violentamente pessoas que já foram dominadas, deitadas no chão. 


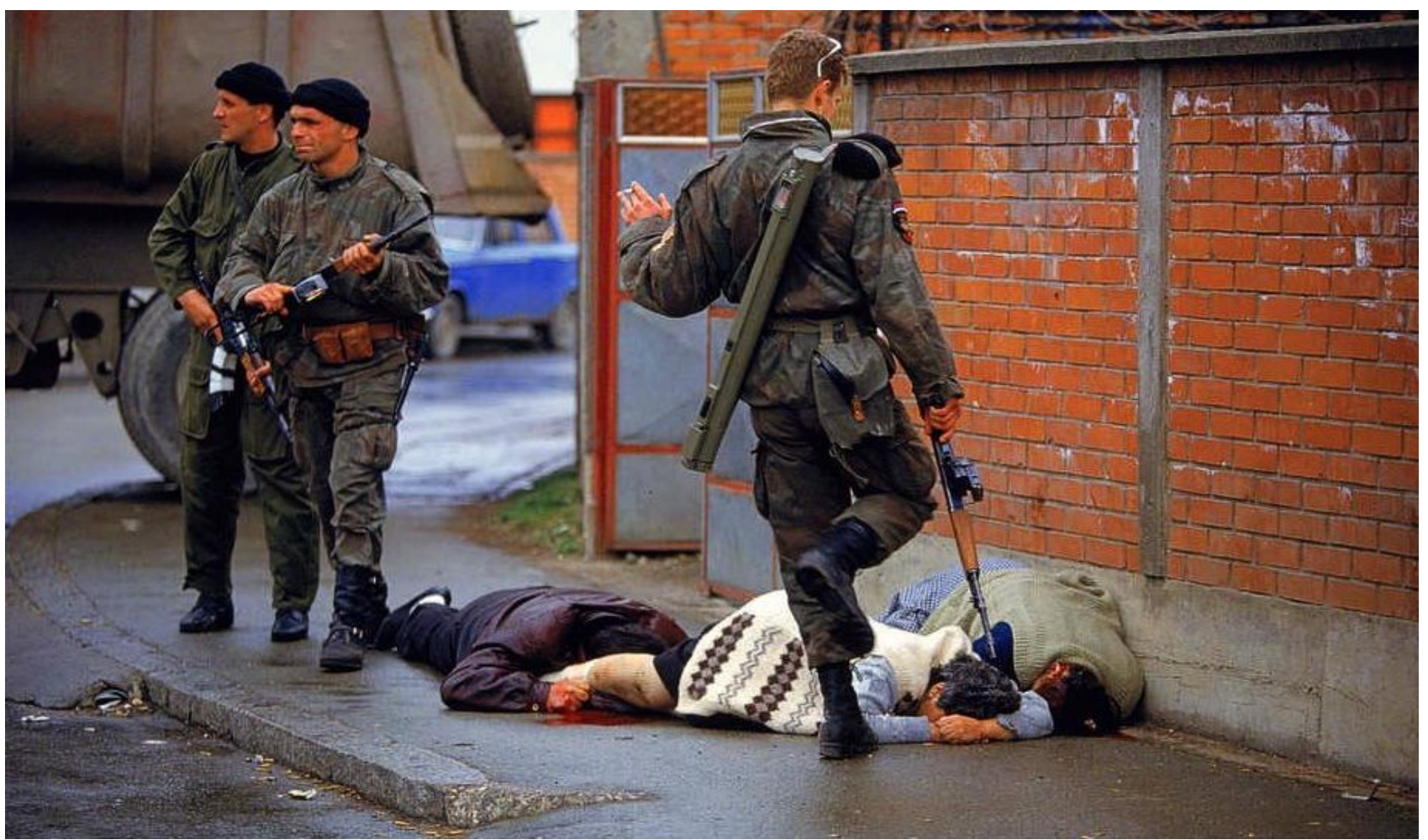

Fonte: Jean Luc Godard, 2'14", 1993.

Narrado pelo próprio Godard, em determinado trecho, a imagem ganha a seguinte descrição:

Cultura é a regra. E arte a exceção. Todos falam a regra: cigarro, computador, camisetas, TV, turismo, guerra. Ninguém fala a exceção. Ela não é dita, é escrita: Flaubert, Dostoiévski. É composta: Gershwin, Mozart. É pintada: Cézanne, Vermeer. É filmada: Antonioni, Vigo. Ou é vivida, e se torna a arte de viver: Srebenica, Mostar, Sarajevo. A regra quer a morte da exceção.(GODARD, 1993)

Ou seja, a cultura é a repetição do status quo, daquilo que é reconhecido por determinado grupo cultural como traço constituinte de sua identidade. A arte é a exceção, aquilo que inicialmente é tratado com desprezo, que desestabiliza a linguagem e a compreensão usual de mundo. Muitas vezes, algo que surge como arte é apropriado pela cultura.

Na mesma direção, o historiador inglês Terry Eagleton mostra sua insatisfação com a palavra cultura, mais especificamente com o modo como ela é exaustivamente citada para determinar modos de viver intocáveis. Por exemplo: ao relativismo cultural não causa estranheza que em países como Arábia Saudita ou no continente africano, crianças sejam circuncisadas ${ }^{6}$ em nome da tradição desses povos, que atribuem a dolorosa mutilação a um ato de purificação. A ativista Fardhosa Mohamed, que descreve a prática como uma "cultura ruim", pergunta-se: se a cultura fere o seu corpo, por que preservá-la? (LUZ, 2014, p. 1). Podemos dizer que, de algum modo, somos mantidos sob a tutela da

\footnotetext{
${ }^{6}$ Em procedimentos como esses, a amputação do clitóris é feita com uma lâmina, na maioria das vezes, sem qualquer tipo de anestesia e antissepsia. Das várias práticas existentes, a infibulação é a mais radical pois costura e fecha toda a extensão da vagina. Mohamed ajuda mulheres que contraem infecções e doenças decorrentes das amputações.
} 
necessidade de cultura e da forma como ela é amplamente conceituada nos dicionários e erguida como uma bandeira pelo bem comum.

As verdades culturais - seja na arte superior ou nas tradições de um povo são por vezes sagradas, devendo ser protegidas e veneradas. A cultura herda, assim, o imponente manto da autoridade religiosa, mantendo, porém, incômodas afinidades com a ocupação e a invasão; e é entre estes dois pólos, positivo e negativo, que o conceito se ergue atualmente. (EAGLETON, 2005, p.10)

O imperativo da nossa cultura, afirma Jorge Larrosa em Pedagogia Profana (2016), produz respostas mecânicas, repetitivas, cuja função é produzir e reproduzir, dessa outra instituição social, agressiva e arrogante chamada "mundo verdadeiro":

A cultura, especialmente a linguagem, é algo que faz com que o mundo esteja aberto para nós. Mas quando uma forma se converte em bordão, em rotina, então o mundo se torna fechado e falsificado. Porque, às vezes, nos livros, nos filmes ou, até mesmo na paisagem, há tantos bordões que nada está aberto. Nenhuma possibilidade de experiência. Tudo aparece de tal modo que está despojado de mistério, despojado de realidade, despojado de vida. (LARROSA, 2016, p. 49)

No entanto, conforme Eagleton: "A cultura, ou o Estado, são uma espécie de utopia prematura que abole a luta a um nível imaginário para que ao nível político não seja necessário fazê-lo" (2005, p.16). Esse nível político é o que diferencia a arte da cultura. Por isso, a compreensão da noção de política estética, de Rancière, torna-se tão importante ao professor de artes. Como escreveu o poeta Manoel de Barros: "Fazer cavalo verde, por exemplo. Fazer noiva camponesa voar - como em Chagall" (2001, p.75), ou seja, arte como forma de ler, pensar e por que não, alterar a percepção e a ordem das coisas no mundo. Nesta conjuntura, concordamos com Rancière na afirmação de que, "A arte é sempre ao mesmo tempo um modo de percepção, um modo de visibilidade e ideia” (2005, p.176).

Para Agamben (2012), o primeiro autor europeu a se dar conta dessa mudança fundamental que tinha ocorrido na transmissibilidade da cultura e na nova relação com o passado foi o filósofo Walter Benjamin. Ele afirmou que não há nenhum documento da cultura que não seja um documento da barbárie: "As citações em minhas obras são como assaltantes de tocaia que atacam com armas o passante e o aliviam de suas convicções"(2000, p. 61).

Ainda sobre o filme de Godard (1993) que narra um acontecimento trágico da história humana, uma cena de guerra, mostra como se mata em nome da cultura e, como arte que é, denuncia e alerta esse perigo. Os artistas são os manipuladores das linguagens artísticas, em cada imagem vista, sentida, discutida, percebida e mesmo traduzida, em sala de aula é possível alargar o entendimento e os significados latentes.

Um caminho apontado por Eagleton parece encontrar uma redenção para a função da cultura na contemporaneidade, ao dizer: "Se, porém, a cultura quiser constituir uma crítica efetiva, terá de manter a sua dimensão social. Não pode simplesmente regredir para o seu significado primitivo como cultivo individual" (2005, p. 23).

O que queremos afirmar é que para pensar a formação do professor de artes visuais na escola contemporânea, é essencial fomentar de maneira profunda e ampla o estudo teórico da filosofia, teoria e história da arte, sem deixar de lado a história, para problematizar os processos criativos dos seus alunos, sujeitos para qual essa formação se destina.

\section{PERSPECTIVAS TEÓRICAS CONTEMPORÂNEAS PARA O ENSINO DA ARTE}


Em Diante do tempo (2015): História da arte e anacronismo das imagens, Georges Didi-Huberman (1953-) considera o tempo como o cerne do pensamento sobre a imagem. Não o tempo cronológico, dos ponteiros dos relógios ou das retrospectivas, mas sim um tempo que aceita outras camadas de tempo sobre ele. Trata-se de um deslocamento interessante se lembrarmos que a história da arte tem abordado a imagem (a pintura, o desenho, a escultura, a fotografia, etc.) como uma questão espacial (de perspectiva, proporção, volume, dimensões, etc.).

Didi-Huberman deixa de lado tanto a ideia positivista da história da arte (que interpreta as obras apenas dentro do contexto em que foram produzidas, proclamando que o "artista é o espelho de seu tempo") quanto a perspectiva da estética clássica (em que beleza é o critério determinante para a análise e apreciação das obras de arte, pressuposto teorizado por Immanuel Kant). A recusa de Didi-Huberman é voltada a uma suposta pureza das imagens, imbuída no conceito clássico de beleza.

Leitor de Friedrich Nietzsche, Didi-Huberman compreende as obras de arte como sobredeterminadas já que são formadas por sobreposições de tempos, interpretações e sentimentos. Por exemplo: um mesmo afresco do pintor florentino Fra Angelico pode ter um sentido na renascença mas assumir outro na contemporaneidade, confundindo-se com o action painting de Jackson Pollock. As imagens podem ser entendidas como montagens de outras imagens cuja complexidade cabe ao professor-pesquisador-artista ${ }^{7}$ indicar e fazer uso de suas várias possibilidades simbólicas junto aos(às) aluno(as).

Uma percepção importante apontada por Didi-Huberman é a de que houve uma "fratura" surgida na história da arte após a Segunda Guerra Mundial. Em tom de denúncia, ele afirma que alguns autores e, consequentemente, a novidade de suas linhas de pensamento, teriam sido quase que apagadas pelo fascismo. Foi o caso de três pensadores judeus-alemãos pertencentes a uma "geração que pagou caro pelo saber" (idem, p. 54): Walter Benjamin (1892-1940), Carl Einstein (1885-1940) e o mais velho deles, Aby Warburg (1866-1929).

Didi-Huberman (2015) lembra que Benjamin, Einstein e Warburg possuíam algo em comum: o fato de terem sido recusados pela academia e de não terem suportado o terror instaurado pela ditadura do Terceiro Reich. Não por acaso, tiveram um destino trágico, os dois primeiros se suicidaram (Benjamin matou-se para não cair nas mãos dos nazistas) e o terceiro Aby Warburg passou o final da vida na clínica Bellevue, na Suíça, a mesma que recebera Friedrich Nietzsche trinta anos antes.

Para Didi-Huberman:

(Tratava-se de um) momento de uma extraordinária fecundidade, porque os pressupostos gerais da estética clássica foram postos à prova por uma filologia rigorosa, e porque essa filologia inversamente se via questionada e reorientada de maneira incansável por uma crítica capaz de colocar o problemas em termos filosóficos precisos (2015, p. 55).

Adorno e Horkheimer, colegas de Benjamin na Escola de Frankfurt, serão ainda mais incisivos ao dizer que uma das lições que a era hitlerista ensinou é a de como é estúpido ser inteligente: "O fato então de que, de repente, os inteligentes são os estúpidos prova para a razão que ela é irrazão" (2015, p.174). A racionalidade, neste caso, é o caráter compulsivo da sociedade alienada de si mesma.

O que foi enterrado com a guerra, esquecido com o pós-guerra pode ser relido agora, segundo Didi-Huberman, pela chave de um triplo desafio: o arqueológico, o anacrônico e o prospectivo:

\footnotetext{
7 Utilizamos aqui o termo professor-pesquisador-artista a partir do conceito de Ricardo Basbaum que em seu livro "Artista-etc" aborda os desdobramentos do trabalho do artista como professor em sala de aula e também como pesquisador.
} 
Arqueológico, para escavar através das espessuras do esquecimento que a disciplina não cessou de acumular sobre suas próprias fundações. Anacrônico, para remontar, a partir do mal-estar, até aqueles que nossos "pais" diretos não mais se sintam filhos. Prospectivo, para reinventar, se possível, um valor de uso para conceitos marcados pela história - a "origem" segundo Benjamin, a "sobrevivência", segundo Walburg, a "modernidade", segundo Carl Einstein [...]. (2015, p. 56)

Carl Einstein recusou o gênero monográfico em busca de uma etnologia da arte, um estudo das condições que produziram as obras, e não um fim em si mesma. Estrategicamente, apropriou-se de um tema até então pouquíssimo abordado pela história da arte europeia e norte-americana: a arte africana. Liliane Meffre, pesquisadora francesa da obra de Einstein, assim resume: "Carl Einstein foi verdadeiramente o descobridor da arte africana, o primeiro teórico ocidental a analisá-la no plano formal com um olhar livre de todo preconceito, de todo etnocentrismo, a lhe conferir, através de seus escritos, um estatuto de arte de pleno direito" (MEFFRE, In: EINSTEIN, 2011, p.07).

O próprio Einstein comentou, logo ao início de Negerplastik, de 1915, ao fazer observações sobre seu método: "Nossa ausência de consideração pelo negro corresponde apenas à ausência de conhecimento a seu respeito, o que só serve para oprimi-lo injustamente". Vale lembrar que Einstein escreveu num período em que ressoavam as ideias baseadas na desigualdade das raças, como as descritas pelo Conde de Gobineau (1816-1882) e que ganhariam legitimação científica nas escalas evolutivas do biólogo e naturalista Ernst Haeckel (1835-1919).

No que diz respeito ao trabalho artístico, os negros eram considerados inaptos, por serem intelectualmente inferiores aos brancos e evolutivamente mais próximos aos macacos. Portanto, além do esforço teórico em trazer a arte africana para o campo discursivo europeu, há um corajoso gesto político ${ }^{8}$ que faz colapsar o eurocentrismo. Não por acaso, toda uma geração de artistas passaria a se interessar não só pela África, mas também pela Oceania e pela América, como André Derain, Georges Braque, Henri Matisse, Joan Miró, Juan Gris, Pablo Picasso e Paul Klee.

Em síntese, o que o pensamento de Carl Einstein propõe é uma inversão da lógica pictórica que até então teria ocupado a arte ocidental. Para isso, ele coloca a plasticidade como conceito mais importante, podendo observá-la na estatuária africana. Enquanto a maior parte das pessoas censuravam "[...] repetidamente nas estátuas negras os supostos erros de proporção", Einstein considerava-os elementos vitais que possuem funções tridimensionais. Este era um modo de rechaçar a frontalidade que havia assolado a arte ocidental até então: "O negro parece ter encontrado uma solução clara e válida para esse problema" (2011, p. 47).

$\mathrm{Na}$ arte e na religiosidade africana, Einstein observa e defende ainda uma outra atitude psíquica. Ao perceber que ao vestir uma máscara em um ritual, o portador se transformava em uma divindade, ele escreveu:

O ser humano sempre se transforma um pouco, esforçando-se, entretanto, em conservar certa continuidade, sua identidade. O europeu faz precisamente desse sentimento o objeto de um culto quase hipertrofiado: o negro, que é menos prisioneiro do eu subjetivo e venera potências objetivas, deve, para se afirmar ao lado delas, converter-se nessas potências, justamente quando as

\footnotetext{
${ }^{8}$ Em 1921, após publicar a sua primeira peça teatral, "A má notícia”, foi processado por blasfêmia pela República de Weimar. A partir de 1928, Carl Einstein se estabeleceu em Paris. Em 1936, partiu para a Espanha para se juntar ao exército popular que, em guerra civil, defendia a liberdade contra o fascismo de Franco. Lutou ao lado dos anarquistas. É um dos últimos a sair da Espanha, em 1939, derrotado, chegando a passar cerca de um mês em um campo de concentração (Argelès), antes de conseguir retornar a Paris, onde novamente é preso e deportado para o campo de Bassens, perto de Bordeaux. Após ser libertado, tenta se suicidar mais uma vez sem sucesso. Logo depois, em julho de 1940, morre ao se atirar às águas do rio Gave de Pau. (apud LEFFRE, p. 11).
} 
festeja de maneira mais fervorosa. Mediante essa metamorfose, ele estabelece um equilíbrio com a adoração que arrisca aniquilá-lo; ele reza para deus, ele dança pela tribo e nesse deus. Essa metamorfose lhe permite aprender radicalmente o que é exterior a ele (grifo nosso); ele encarna em si mesmo e faz-se essa objetividade que reduz ao nado todo evento individual. (EINSTEIN, 2011, p. 57)

À educação, em boa medida, caberia interrogar o ego de cada aluno e se propor como essa experiência de aprendizagem radical do que é exterior a ele, buscando equacionar as diferenças, torná-las objetos não de tolerância, mas de práticas vividas. A alteridade deve também ser assumida pelo aluno e a arte é um espaço privilegiado para a realização disso.

O historiador de arte Aby Warburg abordou a "iconologia do intervalo" visando a desterritorialização da imagem assim como Einstein rompeu fronteiras raciais. Seu objetivo era não restringir a compreensão das imagens apenas aos locais e épocas de origem. O conceito de sobrevivência de traços culturais é central em sua obra. Em "O Ritual da Serpente: arte e antropologia", Warburg encontrou analogias entre os elementos simbólicos presentes no Nascimento da Vênus de Sandro Botticelli, e o ritual das serpentes dos índios pueblos, no Novo México, em 1896. Como relacionar realidades, tempos e contextos culturais tão diferentes?

O protagonista de Marcel Proust, Charles Swann, de "Em Busca do Tempo Perdido", realizava experiências sociais. Ele costumava convidar para os salóes de Odette de Crecy, sua esposa, tanto duques e princesas quanto burgueses vulgares. Aquilo que a sociedade, a política e a economia trataram de organizar era momentaneamente arruinado nos salões de Swann (da mesma forma, aliás, que a escrita de Proust altera a percepção e a experiência do tempo).

E se fosse possível transpor a experiência relacional de Swann/Proust para o campo da educação? Neste caso, por um momento, desarranjar-se-ia aquilo que a história e o currículo ordenaram e hierarquizaram de modo que neste instante de desalinho, de incongruência, poderia se instalar a vertigem capaz de fazer surgir o novo. Na aparente falta de parâmetros, cada sujeito teria de se esforçar para criar suas próprias balizas.

Nesta perspectiva contemporânea de ensino da arte da escola, a imagem na assumiria a forma do palimpsesto ${ }^{9}$, antes do papel, o pergaminho era grosso o suficiente a ponto de que pudesse receber várias camadas de escrita. Muitas vezes, escrevia-se por cima do que já foi escrito, não para negá-lo, mas para começar de novo.

Nas inquietudes que as imagens provocam, reconhecendo que ali existem várias camadas, tendo conhecimento que se necessário for, essa nova camada pode ser raspada e retirada, para se voltar à experiência do antigo, do arcaico. Didi-Huberman escreve "os fatos do passado não são mais coisas inertes a serem encontradas, isoladas, e em seguidas apreendidas numa narrativa causal, o que Benjamin considera como um mito epistemológico" (2015, p.116).

Ao invés de esgotar a leitura de uma imagem, pode-se buscar pelo intervalo dela. É o gesto do professor que mantém aberta a interrogação acerca do que se é e do que está sendo visto. Larrosa resume: "Buscando a permanência no tempo, a continuidade e a estabilidade no tempo, encontrará no próprio tempo o elemento da dessemelhança, da distância e da diferença. Buscando uma identidade substancial, estável e sem falha, encontrará uma identidade narrativa, aberta e desestabilizadora" (2016, p. 41).

\footnotetext{
${ }_{9}^{9}$ Metáfora utilizada tanto por Jean-Jacques Rousseau (1712-1778) quanto por Walter Benjamin (1892-1940).
} 
A imagem toma para si esse movimento numa criação contínua ao passo que o professor poderá conduzir esse percurso que, aliás, pode não ter fim. No modo contemporâneo de ser e de educar, não é problema que perguntas fiquem ressoando sem respostas definitivas. Carl Einstein escreveu que a imagem é um combate, poderíamos dizer também, uma provocação, um despertamento. Por sua vez, Huberman enfatiza a vigilância do professor com a própria prática:

Raramente pousamos um olhar crítico sobre o modo como praticamos nossa disciplina; recusamos, com frequência, questionar a história estratificada, nem sempre gloriosa, das palavras, das categorias, ou dos gêneros literários que empregamos cotidianamente para produzir nosso saber histórico. (DIDI-HUBERMAN, 2015, p.29).

Ao invés de adotar um único vetor temporal, como o passado ou mesmo o presente, uma outra metodologia de ensino da arte pode fazer da estreita relação e trânsito entre o pretérito, o presente e o futuro, uma forma de articular eticamente os conteúdos expostos. Essa concepção, portanto, não se sustenta numa concepção linear do tempo. Ao se optar pela abordagem anacrônica, de encontro à cronologia ordinariamente utilizada pela história e pelas demais ciências, almeja-se proporcionar aos conteúdos e às narrativas dos objetos de estudo modos heterogêneos de compreensão e interação.

A forma de percepção dos grupos humanos se transforma à medida que sua existência também se altera, através de cada período histórico. Essa observação feita por Walter Benjamin, no seu texto $A$ obra de arte na era da reprodutibilidade técnica (1994), abre passagem para entender os movimentos de massas e a difusão das imagens que abarcariam as discussões contemporâneas a partir de meados do século XX.

Para discutir o impacto do início da reprodução em massa de imagens na história, que data do princípio do Renascimento com a imprensa de Johannes Gutemberg, o autor utiliza o conceito de "aura" da obra de arte. Aura é um termo utilizado por Walter Benjamin em seu ensaio, que teve sua primeira versão publicada no ano de 1936. O conceito foi utilizado para designar os elementos únicos de uma obra de arte original. Para o autor, a aura está relacionada à autenticidade. Está ligada também à ideia religiosa, dando à obra de arte um caráter de objeto a ser cultuado, produzindo um "valor de culto".

Segundo Benjamin, "essa história da obra de arte compreende não apenas as transformações que ela sofreu, com a passagem do tempo, em sua estrutura física, como as relações de propriedade em que ela ingressou" (1994, p.167). Em outras palavras, na era da reprodutibilidade técnica perdemos o aqui e agora do original, o conteúdo da autenticidade, a tradição em que se enraíza e identifica o objeto.

A ideia de reprodutibilidade técnica da obra de arte pode ser encontrada ainda nas relações pré-modernas do ensino e do ofício das artes. Lá na relação arcaica existente entre o mestre e o aprendiz, ocorrida nas oficinas em que o conceito de "arte" era ainda distante, sendo o trabalho muito mais próximo de um artesão do que de um artista. Alcançava-se a reprodução de uma obra de arte a partir do método da imitação, utilizada como premissa para o ensino do desenho, da pintura e da escultura.

Não é essa reprodutibilidade técnica, contudo, que Benjamin se refere. Trata-se, para ele, deum processo novo. Inicialmente, a xilogravura, a reprodução da escrita com a invenção da imprensa, a estampa em chapa de cobre e água-forte, a litografia. O processo de reprodução de imagens aconteceu progressivamente, em várias partes do mundo. Entretanto, surgiu um novo e decisivo processo de multiplicação com a chegada da fotografia, "pela primeira vez no processo de reprodução da imagem, a mão foi liberada das responsabilidades artísticas mais importantes, que agora cabiam unicamente ao olho" (2000, p. 167).

Esse novo modo de reprodução será ainda mais potencializado com a chegada do cinema, latente 
ISSN 1983-1579

Doi: 10.22478/ufpb.1983-1579.2019v12n3.46095

http://periodicos.ufpb.br/ojs2/index.php

na fotografia:

Mesmo que essas novas circunstâncias deixem intacto o conteúdo da obra de arte, elas desvalorizam, de qualquer modo, o aqui e agora (...) A autenticidade de uma coisa é a quintessência de tudo o que foi transmitido pela tradição, a partir de sua origem, desde de sua duração material até o seu testemunho histórico. Como esse depende da materialidade da obra, quando ela se esquiva do homem através da reprodução, também o testemunho se perde. Sem dúvida, só esse testemunho desaparece, mas o que desaparece com ele é a autoridade da coisa, seu peso tradicional. (BENJAMIN, 1994, p.168)

Com o cinema, a reprodução da imagem se torna obrigatória. É preciso pagar pela sua produção, muito mais cara do que uma pintura, por exemplo. O cinema é o lugar onde a imagem pode ser vista pelas massas, "é a forma de arte correspondente aos perigos existenciais mais intensos com os quais se confronta o homem contemporâneo" (BENJAMIN, 2000, p.192). Dito de outro modo, a velocidade das imagens da grande tela - que agora se transformou em infinitas pequenas telas, acionadas por celulares e outros dispositivos - não permite o tempo necessário para pensar, quanto mais rápido melhor:

A recepção através da distração, que se observa crescentemente em todos os domínios da arte e constitui o sintoma de transformações profundas nas estruturas perceptivas, tem no cinema o seu cenário privilegiado (BENJAMIN, 2000, p. 194)

A função da arte deixa de ser só social para ser também política, deixa de ser ritualística para ser emancipada. Benjamin marca essa diferença entre dois polos, o valor de culto e o valor da exposição:

A produção de imagens começa com imagens a serviço da magia. $O$ que importa nessas imagens, é que elas existam e não sejam vistas. O alce, copiado pelo homem paleolítico nas paredes de sua caverna, é um instrumento de magia, só ocasionalmente exposto aos olhos dos outros homens; no máximo ele deve ser visto pelos espíritos. O valor de culto quase obriga a manter secretas as obras de arte. (...). À medida que as obras de arte se emancipam do seu uso ritual, aumentam as ocasiões para que elas sejam expostas. (BENJAMIN, 1994, p.173)

É a obra de arte coma aura atrofiada. A consequência dessa sequela impacta além dos campos da arte, porque na medida em que ela se reproduz, substitui a unicidade da obra de arte, por imagens seriadas, que vão ao encontro do espectador. Quanto mais imagens, maior o poder de fixação, independentemente de sua veracidade ou caráter ético.

Podemos dizer que a perda da aura da obra de arte, anunciada por Walter Benjamin, coincide e incide não somente na produção dos artistas das vanguardas artísticas modernistas, mas também na arte que ainda viria a ser produzida no final do século XX e início do século XXI, a chamada arte contemporânea. $O$ perigo anunciado pelo autor de que sem qualquer valor ritualístico tradicional, a arte poderia estar a serviço da estetização da política se concretiza logo em seguida com a Segunda Guerra Mundial, da qual ele próprio seria vítima.

Na primeira metade do século XX, no contexto das intrigas, batalhas e extermínios que as guerras produziriam, alertas já eram emitidos sobre os usos nada desinteressados que as palavras e as imagens vinham assumindo. Começa a ficar evidente que a linguagem opera uma espécie de manipulação e que acabamos por não mais perceber nas palavras, a violência que elas sofrem. 
Na época do mercado livre, a divulgação do nome de uma mercadoria fazia aumentar sua venda. Repetição cega e rapidamente difundida de palavras designadas liga a publicidade à palavra de ordem totalitária. O tipo de experiência que personalizava as palavras ligando-as as pessoas que as pronunciavam foi esvaziado, e a pronta apropriação das palavras faz com que a linguagem assuma aquela frieza que era própria dela apenas nos cartazes e na parte de anúncio dos jornais. (ADORNO,1985, p.137)

Essa constatação foi feita pelos colegas alemães de Benjamin, Theodor Adorno (1903-1963) e Max Horkheimer (1895-1973), em 1944. Em Dialética do esclarecimento (1985), a dita "sociedade do espetáculo"10, que muitos pensadores consideram ser um dos traços centrais da contemporaneidade, era apenas um esboço. Mas ela já podia ser observada na máquina de propaganda de guerra tanto dos Aliados quanto do Eixo. Basta lembrar os espetaculares desfiles do nazismo alemão imaginados por Adolf Hitler.

No capitalismo pós-industrial, o fetiche da mercadoria" tem se aprofundado à medida que a indústria cultural de massa propaga valores simbólicos que são incorporados ao status quo de uma comunidade, agora, inserida no fluxo globalizado de comércio e informações. As observações de Benjamin, Adorno, Horkheimer e Debord estavam corretas e agora é preciso que a escola lide com essas questões em seu cotidiano, caso contrário, a escola apenas absorve e acaba por reproduzir o que é insistentemente repetido pela indústria cultural. Podemos afirmar que os produtos desta indústria estão presentes no repertório escolar, sejam em datas comemorativas ou projetos escolares.

É papel da escola, do professor, e de todos que estão envolvidos no processo de ensinar e aprender, ficar atento para que o discurso esteja afinado com a prática educativa. Como exemplo desse modo de pensar a educação, citaremos em seguida, a ideia central da obra de Jean-Jacques Rousseau (1712-1778), que promove uma reflexão entre o ser e parecer, da oposição discurso e prática.

Deste olhar atencioso e preocupado, em Pedagogia profana (2016), Jorge Larrosa escreve sobre um menino chamado Jean-Jacques que, aos dez anos, foi acusado e castigado injustamente. A acusação: ter quebrado um pente da madame Lambercier, senhora da casa onde estava hospedado. Seus protestos foram inúteis e considerados simples teimosia. Foi duramente castigado por ser, segundo os acusadores, teimoso, arrogante e mentiroso.

A experiência o marcou tão profundamente que ele nunca deixaria de refletir sobre ela. Já adulto, em $1762^{12}$, publicaria Emilio ou Da educação. Hoje considerado o primeiro tratado sobre a filosofia da educação, o livro é dividido em cinco partes e apresenta como seria a educação ideal de uma criança. Não se pode esquecer que, para Rosseau, o ser humano é bom por natureza, sendo corrompido à medida que é inserido nas condições paradoxais e, muitas vezes, incoerentes da vida em sociedade. Emilio, o jovem fictício de Rousseau, teria que deixar o estado de natureza e a infância sem perder a boa índole: eis o papel fundamental da educação.

\footnotetext{
${ }^{10}$ A sociedade do espetáculo é um termo cunhado por Guy Debord, em livro homônimo, de 1967. Ele foi um dos pensadores mais importantes de um movimento conhecido como "situacionismo". Segundo esse grupo, uma determinada sociedade chega ao nível do espetáculo quando todos os aspectos da cultura e da experiência são intermediados por uma relação social capitalista. Ou seja, vivemos em plena sociedade do espetáculo.

${ }^{11} \mathrm{O}$ fetiche da mercadoria é uma ideia apresentada por Karl Marx em O Capital (1867). Em linhas gerais, quer dizer que a mercadoria carrega consigo algo além do valor social do trabalho dedicado para a sua manufatura/produção. De acordo com Marx, esse algo além tem caráter misterioso, fantasmagórico. É o que torna possível que ele assuma um valor irreal e infundado. O mercado de obras de arte é um exemplo cabal disso: em novembro de 2017, a tela "Salvatore Mundi", de Leonardo da Vinci foi vendida por 450 milhões de dólares, ou seja, quase 1 bilhão e meio de reais. É como se a mercadoria perdesse a relação com o trabalho que a criou e ganhasse vida própria, imbuindo-se de significados capazes de refletir valores e nichos sociais.

${ }^{12}$ Neste mesmo ano também foi publicado $O$ contrato social.
} 
Quase ao final da vida, no ano de 1770, em suas Confissões, Rosseau retomou o episódio da acusação. Lembrou-se que até o momento do castigo havia confiança e transparência naquele ambiente. A injustiça, contudo, fez nascer a distância entre as aparências e a verdade. Jorge Larrosa assim interpreta os efeitos do acontecimento: "A injustiça deu a Jean-Jacques a consciência da divisão: um véu cobria a verdade dos sentimentos, a realidade das almas humanas" (2016, p 33). A metáfora do véu trazida por Larrosa faz pensar que existe algo a encobrir aquilo que cada um é. Aquele episódio ensinou o jovem Rosseau a mentir. Aprendendo a enganar o outro, ele aprendeu a mentir para e sobre si mesmo.

A dicotomia entre o ser e o parecer é a oposição básica de toda obra de Rosseau. Por um lado, haveria "[...] todo o seu esforço e seu abismo, para denunciar a aparência e eliminar esse véu ilusório que cobre as coisas e que também se interpõe entre uma pessoa e ela mesma" (Larrosa, 2016, p. 32). Por outro lado, pode existir uma outra postura em busca do ser. Nela, a consciência mantem-se aberta à interrogação, permitindo-se aceitar "[...] o imprevisto e o estranho, o que vem de fora, o que desestabiliza e põe em questão o sentido estabelecido daquilo que se é" $(2016,40)$.

Para isso, deve-se evitar aquilo que Larrosa chama de "fidelidade às palavras" não deixando que elas "[...] se solidifiquem e nos solidifiquem, mantendo aberto o espaço líquido da metamorfose [...] aos textos que nos modelam, aos perigos das palavras que, ainda que sejam verdadeiras, convertem-se em falsas uma vez que nos contentamos com elas" (2016, p.40).

\section{REFLEXÕES FINAIS}

Os autores aqui revisados, encarnam um repertório de perspectivas contemporâneas para o ensino da arte na escola, em que, o professor e do aluno sejam protagonistas de seu tempo e lugar. Esse protagonismo diga-se, não apenas no olhar crítico-reflexivo, mas como sujeitos capazes de se auto reconhecer na produção da história da arte com parâmetros sociais, econômicos e políticos, atentos a vida cotidiana para possibilitar futuras ações no âmbito íntimo, nas relações pessoais e nos grupos sociais. São sobretudo perspectivas teóricas que almejam alterações nos modos de professorar no lugar legítimo e simbólico dessa prática: a sala de aula.

A articulação dessas linhas de pensamento sobre a formação do professor de artes visuais nesta escrita, possuem o intuito de refletir sobre conceitos teóricos essenciais para quem ensina arte na escola. Se houver a compreensão de como a estética, a cultura e a arte são entendidas e produzidas nesse tempo controverso em que vivemos, a arte cumpre a difícil missão de ensinar a pensar e criar com autonomia, um desafio para todos.

A palavra "despertar", quer dizer segundo o dicionário Larousse (1992), sair do estado dormente ou inércia, readquirir força. A partilha do sensível de Rancière é também, podemos dizer, o sinônimo do ensinar/aprender desperto na escola. A estética, por sua vez, adquire no tempo contemporâneo, um viés mais engajado e diríamos também mais crítico, é nesse sentido que sua entrada no campo da política, torna a arte também política, capaz de promover diálogos sobre as diversas realidades.

Se a escola contemporânea vive seus dias de questionamentos de seu papel e sua importância, tomamos a contramão para afirmar que este espaço e esse tempo são fundamentais e até mesmo decisivos para a formação de crianças e adolescentes. Refletir sobre a formação dos professores e como estamos levando arte para a sala de aula é um ato de responsabilidade necessário e diria também, de cuidado e afeto com o outro e com a nossa profissão de educador.

\section{REFERÊNCIAS}

ADORNO, Theodor W., HORKHEIMER, Max. Dialética do esclarecimento. Rio de Janeiro: Zahar, 1985. 
A FORMAÇÃO DE PROFESSORES DE ARTES VISUAISCORÁ, J.; BATTESTIN, C.

AGAMBEN, Giorgio. O homem sem conteúdo. Belo Horizonte, Autêntica Editora, 2012.

BARROS, Manuel de. Livro sobre nada. Rio de Janeiro: Record, 2001.

BENJAMIN, Walter. Magia e técnica, arte e política. São Paulo: Brasiliense, 1994.

BENJAMIN, Walter. Rua de mão única. São Paulo: Brasiliense, 2000.

BENJAMIN, Walter. Passagens. Belo Horizonte: Editora UFMG, 2006.

DEBORD, Guy. A sociedade do espetáculo. São Paulo: Contraponto Editora, 1997.

DIDI-HUBERMAN, Georges. Diante do tempo: história da arte e anacronismo das imagens. Belo Horizonte: Editora UFMG, 2015.

DIDI-HUBERMAN, Georges. A pintura encarnada. São Paulo: Escuta, 2012.

EAGLETON, Terry. A ideia de cultura. São Paulo: Unesp, 2005.

EAGLETON, Terry. A ideologia da estética. Rio de Janeiro: Jorge Zahar, 1993.

EAGLETON, Terry. Depois da teoria: Um olhar sobre os estudos culturais e o pós-modernismo. Rio de Janeiro: Civilização brasileira, 2005.

EINSTEIN, Carl. Negerplastik. Florianópolis: Editora da UFSC, 2011.

GODARD, Jean L. Jevoussalue Saravejo (1993). http://www.youtube.com/watch?v=LU7-07OKuDg. Acessado em 03 de fev. 2018.

KANT, Immanuel. Crítica da Faculdade do juízo. Rio de Janeiro: Forense Universitária, 2002.

LARROSA, Jorge. Pedagogia Profana: danças, piruetas e mascaradas. Belo Horizonte: Autêntica, 2016.

LAROUSSE. Dicionário da Língua Portuguesa. São Paulo: Nova Cultural, 1992.

MARTINS, Mirian Celeste; Picosque, Gisa. Mediação cultural para professores andarilhos na cultura. São Paulo: Intermeios, 2012.

MATISSE, Henri. Escritos e reflexões sobre arte. São Paulo: Cosac Naify, 2007.

NIETZSCHE, Friedrich. Genealogia da Moral. São Paulo; Editora Brasiliense, 1988.

POST, Frans. In: ENCICLOPÉDIA Itaú Cultural de Arte e Cultura Brasileiras. São Paulo: Itaú Cultural, 2017.

PROUST, Marcel. Em busca do tempo perdido: No Caminho de Swann. Rio de Janeiro, Editora Globo, 1993.

RANCIÉRE, Jacques.A partilha do sensível.São Paulo: Editora 34, 2005.

RANCIÉRE, Jacques.O mestre ignorante. Belo Horizonte, 2007.

RANCIÉRE, Jacques. O destino das imagens.Rio de Janeiro:Contraponto, 2012.

RANCIÉRE, Jacques. Políticas da escrita. Rio de Janeiro: Ed 34, 1995.

RILKE, Rainer Maria. Cartas a um jovem poeta. Rio de Janeiro: Globo, 1953. 
ISSN 1983-1579

Doi: 10.22478/ufpb.1983-1579.2019v12n3.46095

http://periodicos.ufpb.br/ojs2/index.php

WARBURG, Aby. A renovação da antiguidade pagã: contribuições científico-culturais para a história do Renascimento. Rio de Janeiro: Contraponto, 2013.

WARBURG, Aby. Le Rituel du Serpent: art \& anthropologie. Paris: Macula, 2003.

GODARD, Jean-Luc. Jevoussaluesaravejo. 1993. Filme. (2 min e 14 seg)

Disponível em: http://www.youtube.com/watch?v=LU7-07OKuDg. Acesso em 03 de fev. 2018.

LUZ, Natália da. Por dentro da África. 2014. Disponível em: http://www.pordentrodaafrica.com/default/circuncisao-feminina-se-a-cultura-fere-o-seu-corpo-por-quemanter-esse-costume-diz-ativista-fardhosa-mohamed. Acesso em 04 de fev. 2018.

Recebido em: 25/05/2019

Aceito em: $14 / 08 / 2019$

Publicado em: 03/10/2019 